\title{
Production of leaf wax $n$-alkanes across a tropical forest elevation
}

\section{transect}

Sarah J. Feakins ${ }^{\mathrm{a} *}$, Tom Peters ${ }^{\mathrm{a}}$, Mong Sin Wu ${ }^{\mathrm{a}}$, Alexander Shenkin ${ }^{\mathrm{b}}$, Norma Salinas ${ }^{\mathrm{b}, 1}$, Cécile A.J. Girardin ${ }^{\mathrm{b}}$, Lisa Patrick Bentley ${ }^{\mathrm{b}}$, Benjamin Blonder ${ }^{\mathrm{b}}$, Brian J. Enquist ${ }^{\mathrm{c}}$, Roberta E. Martin ${ }^{\mathrm{d}}$, Gregory P. Asner ${ }^{\mathrm{d}}$, Yadvinder Malhi ${ }^{\mathrm{b}}$

a Department of Earth Sciences, University of Southern California, 3651 Trousdale Pkwy, Los Angeles, CA 90089, USA

${ }^{\mathrm{b}}$ Environmental Change Institute, School of Geography and the Environment, University of Oxford, South Parks Road, Oxford, OX1 3QY, UK

${ }^{\mathrm{c}}$ Department of Ecology and Evolutionary Biology, University of Arizona, AZ 85721, USA

${ }^{\mathrm{d}}$ Department of Global Ecology, Carnegie Institution for Science, 260 Panama St, CA 94305, Stanford, USA

${ }^{*}$ Corresponding author. Tel.: 2137407168.

E mail address: feakins@usc.edu (Sarah J. Feakins).

${ }^{1}$ Permanent address: Seccion Química, Pontificia Universidad Católica del Perú, Perú. 


\section{ABSTRACT}

Waxy compounds form the boundary layer of the living leaf and contribute biomarkers to soils, and lake and marine sediments. Cataloguing the variation in leaf wax traits between species and across environmental gradients may contribute to the understanding of plant functional processes in modern ecosystems, as well as to calibration efforts supporting reconstruction of past ecosystems and environments from the sedimentary archives of leaf wax biomarkers. Towards these goals, we have surveyed the distributions of leaf wax $n$-alkanes in trees from the lowland tropical rainforest (TR) and montane cloud forest (TMCF) of Perú. Molecular abundances were quantified via gas chromatography flame ionization detection (GC-FID) for 635 individuals, 152 species, 99 genera and 51 families across 9 forest plots spanning $0.2-3.6 \mathrm{~km}$ elevation. We found the expected abundance distributions; for example, they were dominated by long chain, odd numbered $n$-alkanes, especially $\mathrm{C}_{29}$ and $\mathrm{C}_{31}$. New observations included a tendency to increasing total alkane concentration at higher elevation. We propose that the well known leaf economic strategy to increase leaf mass per unit area with elevation, provides a theoretical basis for understanding the increase in leaf wax $n$-alkane abundance with elevation: we infer an increased investment in foliar defense associated with increased leaf lifespan and in response to environmental pressures including cloud immersion and declining temperature. Furthermore, we combined measurements of $n$-alkane concentration with estimates of forest productivity to provide new ways to quantify ecosystem-scale forest alkane productivity. We introduce a new concept of $n$-alkane net primary productivity ( $\mathrm{NPP}_{\text {alk}}$; the product of alkane concentration and leaf NPP) and find that alkane productivity estimates ranges from 300-5000 $\mathrm{g} \mathrm{C} / \mathrm{ha} / \mathrm{yr}$ associated with ecological and environmental changes across the elevation profile.

Keywords: Amazon; Andes; CHAMBASA; leaf wax; Perú; NPP 


\section{Introduction}

Terrestrial plant leaves are covered with wax, comprising mixtures of long chain hydrocarbons, including $n$-alkanes, as well as $n$-alkanols, aldehydes, fatty acids and wax esters, with the $n$ alkanes commonly dominant (Eglinton and Hamilton, 1967). The components are synthesized early in leaf ontogeny (Jetter and Schaffer, 2001) and are likely not substantively regenerated during the lifespan of the leaf (Kahmen et al., 2013a; Tipple et al., 2013), although replacement following removal of surface wax has been demonstrated (Jetter and Schaffer, 2001). The epicuticular and intracuticular wax on plant leaves serves to protect the plant from desiccation, and from pathogen and fungal attack, as well as altering leaf wettability and runoff (Koch et al., 2009). This protective role may extend to other functions, including protection from UV radiation (Shepherd and Griffiths, 2006). Many of these functions would be expected to vary across elevation gradients, which carry gradients in temperature, precipitation, insolation and biotic stress.

The abundance distribution of leaf wax components varies between species (Diefendorf et al., 2011). Of the long chain $n$-alkanes, with formula $\mathrm{C}_{n} \mathrm{H}_{2 n+2}$, where $n$ typically is 21 to 35 , typically one or two chain lengths are dominant or co-dominant and distributions have a strong odd/even preference resulting from chain elongation by acetate units followed by decarboxylation (Eglinton and Hamilton, 1967). Discrete applications where $n$-alkane distributions are diagnostic may be the exception rather than the rule; for example, Sphagnum spp. in peat bogs dominantly make $\mathrm{C}_{23}$ (Bingham et al., 2010), whereas Juniperus virginiana dominantly makes $\mathrm{C}_{35}$ (Tipple and Pagani, 2013) but these components are rarely dominant in other species. Some studies have suggested that chain length distributions can be used to discern shifts in vegetation communities such as forest-grassland transitions in the high Andes (Jansen et al., 2010) or grassland-succulent 
plant transitions in southern Africa (Carr et al., 2010). Variation in distributions has also been suggested to be a response to temperature or aridity at the time of leaf production in J. virginiana (Tipple and Pagani, 2013) or aridity in Acacia and Eucalyptus (Hoffmann et al., 2013). Studies of atmospheric dust (Kawamura et al., 2003) and marine sediments (Castaneda et al., 2009) provide supporting evidence for these suggested relationships between chain length and temperature or aridity. However, the variety of distributions between species appears to confound the search for globally consistent environmental responses in leaf wax alkane distributions (Bush and McInerney, 2013). The diversity of distributions might therefore be expected to be greatest in regions of high phylogenetic diversity (Ter Steege et al., 2010) and functional diversity (Silman, 2014), such as biodiverse tropical rainforests.

\subsection{Tropical plant leaf wax studies}

There is little direct work on living plants in lowland tropical ecosystems in terms of characterizing leaf wax composition (Vogts et al., 2009; Garcin et al., 2014; Graham et al., 2014). Those studies focused on carbon isotopic variation as well as molecular abundance distributions of a few species in central Africa and Central America. Across a forest-grassland transition in Cameroon the varying proportions of wax production in different chain lengths were shown to impact the overall isotopic signature contributed to sediments, with the $\mathrm{C}_{4}$ grass types contributing $\mathrm{C}_{33} n$-alkane with a concentration equal to or in excess of $\mathrm{C}_{3}$ species, whereas $\mathrm{C}_{3}$ trees and shrubs produced many times more $\mathrm{C}_{29}$ and $\mathrm{C}_{31}$ than $\mathrm{C}_{4}$ grasses (Garcin et al., 2014). Whether the varied concentration of wax on the leaves of different species may bias the sedimentary signal is an important question for further investigation.

In the Andes, plant leaf wax in living plants in the tropical montane forests and páramo (alpine tundra, mostly grass) in the Ecuadorian Andes has been studied (Jansen et al., 2006). In almost 
all the plants, $\mathrm{C}_{29}$ and $\mathrm{C}_{31}$ were the dominant $n$-alkanes with the expected odd preference (Jansen et al., 2006; Jansen and Nierop, 2009). The $\mathrm{C}_{29} / \mathrm{C}_{31}$ ratio has been suggested as an indicator of the forest-páramo transition in the Ecuadorian Andes, with paleoenvironmental reconstruction using this as well as other aspects of molecular abundance distribution and pollen (Jansen et al., 2010, 2013). The absolute concentrations have been found to vary greatly between species and plant type, with concentration of $\mathrm{C}_{29}$ ranging between negligible and up to $1600 \mu \mathrm{g} / \mathrm{g}$. However, in these Andean studies, plant sampling extended to no lower than $3.5 \mathrm{~km}$, leaving the western Amazon unstudied.

\subsection{Elevation transect}

The western Amazon contains some of the highest plant species diversity in the world (Ter Steege et al., 2010). This high biodiversity adjacent to the Andes may not be unrelated: the uplift of the Andes dramatically altered landscape and climate, and may have contributed to species diversification (Hoorn et al., 2010). The Eastern Cordilleran uplift began with the "Incaic pulse" of uplift of the central Peruvian Andes during the Eocene and this phase was complete by $40 \mathrm{Ma}$ (Noble et al., 1979). A fully forested elevation transect across the eastern flank of the Andes has been sampled by a series of plots that allow, amongst other things, the study of tree species

diversity (Silman, 2011), forest productivity (Girardin et al., 2014a; Huacara Huasco et al., 2014; Malhi et al., 2014) and the effect of environmental variables on plant traits (Malhi et al., 2010; Asner et al., 2014a,b; Asner et al., 2016b; Girardin et al., 2014b). This transect of forest plots has recently been used to study plant water and leaf wax hydrogen isotopic composition, with plants found to encode the isotopic composition of meteoric water in the leaf wax $n$-alkane and $n$ alkanoic acids (Feakins et al., 2016). 
From this same network, we have analyzed a large set of leaf samples, in total sampling 639 individual trees, of which 158 species from nine sites, greatly expanding the catalogue of leaf wax $n$-alkane abundance information on tropical trees. The study provides new insights into the patterns of individual and community $n$-alkane abundance and molecular composition to reveal landscape and ecosystem-scale assessments of tropical forest leaf wax $n$-alkane production.

\subsection{Geological relevance}

Leaf wax $n$-alkanes are of geological interest as they are notably resilient tracers of past plant production. Leaf wax, abraded by wind, water or insects, or carried on senescent leaves into leaf litter and soils, may be stored, or eroded and transported further to lake and ocean sediments (Hemingway et al., 2016). In the high Ecuadorian Andes (> $3.5 \mathrm{~km}), n$-alkane storage times in soils have been estimated to span several millennia (Jansen and Nierop, 2009). Some fraction of the leaf wax may be remineralized by microbial activity, but the wax components are more recalcitrant than many biochemicals produced by plants, so their proportion in sedimentary organic matter increases as other more labile compounds such as carbohydrates and cellulose are degraded (Hedges and Oades, 1997). Of the leaf wax components, $n$-alkanes are commonly used in palaeoenvironmental studies, including records that extend back over at least 55 Ma into the hyperthermal conditions of the Paleocene-Eocene Thermal Maximum (Pagani et al., 2006;

Handley et al., 2012; Krishnan et al., 2015). They therefore have the potential to inform on the long term evolution of the Amazon rainforest (Hoorn et al., 2010), in suitable sedimentary archives. They have been studied in soils, as well as in fluvial sediments exported by the Kosñipata and Madre de Dios rivers draining the eastern flank of the Andes down to the Amazonian lowlands, with their hydrogen isotopic composition tracing their elevation of origin and downstream integration across the catchment and informing on modern transport and storage 
processes (Ponton et al., 2014). Leaf wax $n$-alkane distributions in soils have been studied to reconstruct the forest-páramo transition at high elevation in the Ecuadorian Andes over millennia (Jansen et al., 2010; Jansen et al., 2013). The same compounds in the surface sediments of lakes have been studied and their hydrogen isotopic composition used to discern spatial variation in aridity (Polissar and Freeman, 2010). Hydrogen isotopic composition has been used to reconstruct past changes in hydroclimate across the last glacial and the Holocene, with a record spanning 12,000 yr from Lake Titicaca (Perú/Bolivia; Fornace et al., 2014), as well as in a smaller lake setting, where ecological changes in the vegetation community superseded the hydroclimate signal (Fornace et al., 2016). Prior marine sediment reconstruction using leaf wax components around South America has informed on the late Pleistocene from the Cariaco Basin off Venezuela (Hughen et al., 2004). As leaf wax components may be preserved in geological deposits for millions of years (Hedges and Oades, 1997), they have been used for paleoaltimetry in the Andes (Kar et al., 2016) and there is potential for future work on Neogene and older leaf wax components within continental drilling in the Amazon basin (Baker et al., 2015), as well as for reconstruction from marine sediments of the Amazon Fan. The goal of better understanding the significance of the leaf wax legacy of ancient ecosystems in tropical paleoenvironmental sedimentary records motivates studies of living forests across environmental gradients.

\section{Material and methods}

\subsection{Study site}

The study included 9 plots (Fig. 1; Table 1) that belong to a group of permanent 1 ha plots operated by the Andes Biodiversity Ecosystems Research Group (ABERG, http://www.andesconservation.org) and that are part of the ForestPlots (https://www.forestplots.net/) and Global Ecosystems Monitoring Network (GEM; 
http://gem.tropicalforests.ox.ac.uk/projects/aberg) networks. Five montane plots are in the Kosñipata Valley in the province of Paucartambo, in the department of Cusco, Perú, two are submontane plots in the Pantiacolla front range of the Andes and two lowland plots are in Tambopata, in the department of Madre de Dios, Perú (Malhi et al. 2010). All the plots are in areas with relatively homogeneous soil substrates and stand structure, and minimal evidence of human disturbance (Girardin et al., 2014a). The sites are placed to allow sampling across the profile, to characterize the full range of forest and climate. The highest is just below the treeline transition to puna (grassland); two bracket the cloud base and two lowland sites test the influence of proximity to the river (Fig 1). The lowland plots were established in the early 1980s and the montane ones between 2003 and 2013, with all stems $\geq 10 \mathrm{~cm}$ diameter at breast height tagged and identified to species level; the plots have been annually measured for carbon allocation and cycling following standard GEM Network protocol (Marthews et al., 2014). As such, net primary productivity estimates (Girardin et al., 2010) and comprehensive descriptions of the carbon cycle exist for many of the plots (Girardin et al., 2014b; Huaraca Huasco et al., 2014; Malhi et al., 2014; Malhi et al., 2015). Mean annual air temperature spans 9-24.4 ${ }^{\circ} \mathrm{C}$ and precipitation 1560 $5302 \mathrm{~mm} / \mathrm{yr}$ along the gradient (Table 1).

\subsection{Field sampling}

From April - November 2013, plant traits in all plots were measured as part of the CHAMBASA project. Based on the most recently available census and diameter data, a sampling protocol was adopted, wherein species that maximally contributed to plot basal area (a proxy for plot biomass or crown area) were sampled. Within each species, 3-5 individual trees were chosen for sampling (5 in upland sites and 3 in lowland sites). If 3 trees were not available in a plot, additional individuals of the same species from an area immediately surrounding the plot were 
sampled. Using tree climbing techniques, leaf samples from one fully, sunlit canopy branch (of at least $1 \mathrm{~cm}$ diameter), were taken from each tree. Some companion shade leaves were selected for other projects. From each branch, measurements were taken of 5 leaves from simple leaved species, or 5 individual leaflets from compound leaved species (both referred to as 'leaf' below) for trait measurements. In the case of compound leaves, the entire compound leaf was also collected for whole leaf area calculations. Leaves were chosen with minimal damage (i.e. herbivory). They were placed in coolers from the field plot to the field lab for drying, at low temperature (ca. $50{ }^{\circ} \mathrm{C}$ ), and thereafter stored in paper envelopes prior to lipid analysis. The sample set for $n$-alkane quantification included 639 individual samples distributed across 9 forest plots, including 158 species from 105 genera and 55 families.

\subsection{Lipid extraction}

The dried leaves were cut using solvent-cleaned scissors and were extracted by immersion in dichloromethane $(\mathrm{DCM}) / \mathrm{MeOH}(9: 1 \mathrm{v} / \mathrm{v})$ with agitation using a Pasteur pipette, with extraction repeated $3 x$. The extract was separated into two fractions using column chromatography $(5 \mathrm{~cm} \mathrm{x}$ $4 \mathrm{~mm}$ Pasteur pipette, 5\% water-deactivated silica gel, 100-200 mesh), eluting first with hexane (alkane fraction), followed by DCM, and $\mathrm{MeOH}$ (remainder). Only the alkane fraction was analyzed here.

\section{4. $n$-Alkane identification and quantification}

The alkane fraction was analyzed using gas chromatography-mass spectrometry (GC-MS; Agilent Technologies ${ }^{\circledR}$ ) with a split for flame ionization detection (FID). FID peak areas were manually integrated to quantify $n$-alkanes in the range $\mathrm{C}_{21}$ to $\mathrm{C}_{35}$, relative to daily analysis of an in-house mixture of $n$-alkanes of known abundance. Component identification was based on MS. We report the abundance for each chain length and also report the modal chain length $\left(\mathrm{C}_{\max }\right)$. We 
calculate the average chain length (ACL), the weighted average accounting for concentration $\left(C_{n}\right)$ of each compound (n) computed as:

$$
\mathrm{ACL}=\Sigma\left(\mathrm{C}_{\mathrm{n}} \cdot \mathrm{n}\right) / \Sigma \mathrm{C}_{\mathrm{n}}
$$

where $\mathrm{n}=27$ to 33 .

The $n$-alkanes were summed as:

$$
\text { Salk }=\sum_{\mathrm{i}}^{\mathrm{n}}\left[\mathrm{C}_{\mathrm{n}}\right]
$$

where $\mathrm{n}=\mathrm{C}_{21}$ to $\mathrm{C}_{35}$. This sum can be considered as concentration relative to per unit dry leaf mass $(\mu \mathrm{g} / \mathrm{g})$ or per unit leaf lamina area $(\mu \mathrm{g} / \mathrm{cm})$. In order to consider C fixation, concentration can be converted from $\mu \mathrm{g} / \mathrm{g}$ (dry leaf tissue) to $\mu \mathrm{g} / \mathrm{g} \mathrm{C}$, by accounting for the molar fraction of $\mathrm{C}$ in both alkanes and dry bulk leaf tissue. The molar fraction of $\mathrm{C}$ is 0.8529 for $\mathrm{C}_{29}$, the dominant chain length and, within error, the result is insensitive to the choice of chain length, making it unnecessary to account for variation in molecular distribution. For leaf biomass (ca. 50\% C), we used the measured $\mathrm{C}$ content of leaf biomass on a per species basis. Each of these ways of evaluating the alkane concentration was used for calculations and comparisons.

We calculated the carbon preference index $(\mathrm{CPI})$ as:

$$
\mathrm{CPI}=2 \Sigma \mathrm{C}_{\mathrm{n}} /\left(\Sigma \mathrm{C}_{\mathrm{n}-1}+\Sigma \mathrm{C}_{\mathrm{n}+1}\right)
$$

where $n=27-33$. For comparison, we also calculated the ratio of two common chain lengths, $\mathrm{C}_{29} / \mathrm{C}_{31}$, as this index has been reported elsewhere for the Andes (Jansen and Nierop, 2009).

\subsection{Community average}

We analyzed the distribution of leaf wax traits for individuals and calculated medians and unweighted means of all sampled individuals at each forest plot. Means are influenced by outliers, resulting in biased central estimates when data distributions are highly skewed, where 
medians are more appropriate measures of the central tendency. The numbers of individuals and species sampled, as well as the proportion of the forest represented by the sampled species, each informs on the representation achieved from our sampling.

Leaf wax traits for individuals were averaged at the species level within each forest plot, and we computed weighted mean values that accounted for the proportional contribution of each species, based on estimates of biomass. To estimate biomass, we used tree trunk diameter at breast height from the year with the most recent census data. While census year ranged between 2009 and 2014, it was not expected to bias analysis since plots were old growth and had not experienced major disturbance (e.g. landslide, fire, deforestation) during that time. We account for the total basal area of each sampled species within the forest plot in the weighting. For ACL, CPI and $\mathrm{C}_{29} / \mathrm{C}_{31}$, the community weighting accounts for variation in both species basal area and alkane concentration. The weighted mean $(\mathrm{cwm})$ and the weighted standard deviation $\left(\sigma_{\mathrm{w}}\right)$ for each trait at the plot level were estimated using:

$$
\begin{aligned}
& c w m=\Sigma C_{i}^{n} W_{i} \cdot x_{i} / \Sigma C_{i}^{n} W_{i} \\
& \sigma_{w}=V\left(\sum_{i}^{n} W_{i}\left(x_{i}-c w m\right)^{2} / \Sigma_{i}^{n} W_{i}\right)
\end{aligned}
$$

where $\mathrm{x}_{\mathrm{i}}$ is the value and $\mathrm{w}_{\mathrm{i}}$ the weight for the $\mathrm{i}^{\text {th }}$ species. Note that this species weighting approach accounts for interspecies variation and contribution, but does not propagate intraspecific variation (working shown in Appendix A).

We report the median, unweighted and community-weighted mean values for each forest plot to identify the central tendency and the uncertainty in our estimates, as each approach carries known and unknown inaccuracies. For example, median and unweighted mean values do not 
account for biomass, but weighted mean and unweighted mean values for small numbers of samples carry the unquantified uncertainty of small samples of the species they average, particularly where distributions are skewed. Comparison between central estimates thus provides a more comprehensive measure of uncertainty than provided by the standard errors of the mean.

\subsection{Alkane productivity at plot level}

Average production of alkanes as a fraction of leaf biomass on a stoichiometric basis can be connected with $\mathrm{NPP}_{\text {leaf }}$ estimates for each plot (Girardin et al., 2014a; Huaraca Huasco et al., 2014; Malhi et al., 2014) to generate estimates of the net primary productivity of leaf wax $n$ alkanes $\left(\mathrm{NPP}_{\mathrm{alk}}\right)$, a term newly coined here:

$$
\mathrm{NPP}_{\mathrm{alk}}=\sum \text { alk } \cdot \mathrm{NPP}_{\text {leaf }}
$$

where $\Sigma$ alk refers to the $n$-alkane concentration per site in $\mu \mathrm{g} / \mathrm{g} \mathrm{C}$ (variously using the median, unweighted mean of individuals or community-weighted mean of species), and NPP leaf the leaf net primary productivity in $\mathrm{Mg} \mathrm{C} / \mathrm{ha} / \mathrm{yr}$. $\mathrm{NPP}_{\text {alk }}$ was determined for each site and is reported in units of $\mathrm{g} \mathrm{C} / \mathrm{ha} / \mathrm{yr}$ with propagated uncertainty. We report the numbers of samples and species collected, as well as the proportion of forest community represented by these species, to describe how much of the forest has been characterized as well as the limits of the sampling that contribute to uncertainty.

\section{Results}

\subsection{Distribution of n-alkanes}

We found $n$-alkanes in the range $\mathrm{C}_{21}$ to $\mathrm{C}_{35}$, and their abundance was determined for 552 individual tree samples, species average and site average (Appendix A), revealing considerable variability in the distributions. To illustrate average distributions, we summarize the mean of the 
relative molecular abundance distributions of all individuals 552 individuals (Fig. 2). $\mathrm{C}_{29}$ and $\mathrm{C}_{31}$ were dominant across all sites, with abundance ranging from 20 to $430 \mu \mathrm{g} / \mathrm{g}$ ( $n$-alkane homolog abundance per unit mass of dry leaf). $\mathrm{C}_{27}$ was present in low abundance at the lowland sites, but was more abundant at higher elevation, albeit with lower maxima than $\mathrm{C}_{29}$ and $\mathrm{C}_{31}$. Most other odd homologs (i.e. $\mathrm{C}_{21}$ to $\mathrm{C}_{25}$, and $\mathrm{C}_{33}$ to $\mathrm{C}_{35}$ ) and all even homologs were in low abundance throughout $(<30 \mu \mathrm{g} / \mathrm{g})$.

The putative Andean forest marker, $\mathrm{C}_{29} / \mathrm{C}_{31}$, ranged from $<1$ up to 128 (Fig. 3a), with most individuals having values $<10$, with high values in just a few species (Weinmannia bangii, Hedyosmum goudotianum and H. cuatrecazanum). We also report the widely used CPI, often used in sedimentary applications as a test of plant source (CPI > 4) vs. an indicator of diagenesis $(\mathrm{CPI}<4)$. In this large tropical forest survey, CPI was highly variable between individuals and species, ranging between 1 and 53, with an overall mean of $31(\sigma=9$, range $1-53, n=552$; Fig 3b). Notably, 80 individual plants, or $15 \%$ of the tropical trees sampled, had CPI $<4$.

\subsubsection{Data not included in the survey}

Of the 639 samples, 54 individuals were excluded from further calculations, because of chromatographic issues, typically, the non-determination of even $n$-alkanes. In such samples this was due to the presence of other compounds, suspected to be esters at the same point in the chromatogram. An additional 29 samples, collected outside the CHAMBASA tree canopy survey, mostly understory collections at cloud forest site ESP-01, as well as some lianas (vinelike growth forms), are reported as additional data. The additional data (82 individuals) are reported separately in Appendix A, but were not analyzed further as part of the canopy survey effort.

\subsection{Average Chain Length (ACL)}


The $n$-alkane abundance distribution (Fig. 2) is commonly summarized by way of the ACL. ACL was highly variable, ranging from 27.2 to 32.6 overall (Fig. 4), with up to 2 to 5 units of range between individuals at any site. Interspecies variability appeared to capture much of this range, although the range of intraspecies variability and small number of samples of each species meant that the species mean values were not well defined. The unweighted mean ACL of all individuals at each site displayed a one-unit tendency to longer chain length at lower elevation. Linear regression of ACL data with site mean annual air temperature (MAAT) gave ACL $=0.07$ MAAT + 28 (for individual data $r^{2} 0.19 ; p<0.05$; for site mean values $r^{2} 0.90 ; p<0.05$ ).

\subsection{Alkane concentration}

$\sum$ alk varied from 1 to $5225 \mu \mathrm{g} / \mathrm{g}$ dry leaf mass (Fig. 5a). For clarity, we emphasize that wax is a very small component of the leaf, accounting for just $1.12 \%(1 \sigma=0.05 \%, n=552)$ on average, from a minimum of $0.0001 \%$ to no higher than $5.2 \%$ on a leaf mass basis. On a stoichiometric basis, $\Sigma$ alk ranged from 2 to $9766 \mu \mathrm{g} / \mathrm{g} \mathrm{C}$ (Fig. 5b). While leaf wax concentration data are commonly reported in concentration units as above, leaf wax is not dispersed through the leaf but is deposited as a layer on the leaf surface and, as with other surficial leaf traits, may be better considered on an area basis. Here, individual $\Sigma$ alk values spanned a range of 0.01 to $81 \mu \mathrm{g} / \mathrm{cm}$ on a leaf area basis (Fig. 5c).

The concentration data were highly skewed (Fig. 6a) and the distributions of individual data and central estimates are displayed in violin plots in Fig. 6b. Intraspecies variability was high, so species mean values were not well-determined from small sample sizes (3-5 individuals of a species). Examples of species with high alkane concentration per unit area included Clethra cuneata (Clethraceae) and Myrsine coriaceae (Primulaceae) and examples of the many species 
with low concentration included Guatteria glauca (Annonaceae) and Elaeagia mariae (Rubiaceae). Despite the variability in alkane concentration between individuals, a significant transition occurred between the TR (lower alkane concentration) and TMCF (higher alkane concentration) between 1.5 and $1.7 \mathrm{~km}$ (Fig. 6b; with mean values being significantly different from Student's $\mathrm{t}$ test), corresponding to the transition from sub-montane forest to tropical montane cloud forest. Above $1.7 \mathrm{~km}$, maximum values for a few individuals and mean values remained high, but distributions and median values revealed that $\Sigma$ alk for most individuals dropped in the highest elevations again (Fig. 6b). However, influenced by the high $\Sigma$ alk values of some individuals of dominant species, community-weighted mean values increased further with elevation. We therefore observed a divergence between total alkane concentration estimates from forest plot central estimates with elevation within the TMCF median (decreasing), mean (plateau) and community weighted mean (increasing) (Fig. 7b). For skewed data distributions the median is advised, but as trends are dependent upon statistical choices, at the highest sites, particularly ACJ-01, uncertainties were revealed from the comparison between central estimates.

\subsection{Forest plot alkane productivity}

In order to assess productivity, we combined observations that $n$-alkane concentration tended to increase across the profile (Fig. 8a), with observations that $\mathrm{NPP}_{\text {leaf }}$ decreases with elevation (Girardin et al., 2014a; Huaraca Huasco et al., 2014; Malhi et al., 2014; Table 2, Fig. 8b). The product of these two measures, from Eq. 6, yielded NPPalk estimates (Fig. 8c). NPP alk plot-level ranged from 321 to $2276 \mathrm{~g} / \mathrm{ha} / \mathrm{yr}$ based on median alkane concentration, 552 to $3361 \mathrm{~g} / \mathrm{ha} / \mathrm{yr}$, based on the unweighted mean alkane concentration, and 595 to $5123 \mathrm{~g} / \mathrm{ha} / \mathrm{yr}$, using the community-weighted approach. For the lowland tropical rainforest, distal from the river (TAM05) we estimated NPP alk to be $1098-1513 \mathrm{~g} / \mathrm{ha} / \mathrm{yr}$, depending on estimation method, and we saw 
lower productivity closer to the river (TAM-06; 686-1199 g/ha/yr). From low alkane

productivity in sub-montane forests at $0.6 \mathrm{~km}(\mathrm{PAN}-02 ; 340-944 \mathrm{~g} / \mathrm{ha} / \mathrm{yr})$, we found a robust increase in NPP ${ }_{\text {alk }}$ with elevation to $2.9 \mathrm{~km}$ (ESP-01; 2244-3361 g/ha/yr). TMCF plots ( 3 sites) between 1.7 and $2.9 \mathrm{~km}$ had notably higher alkane production rate values at approximately double or triple those of the lowland and sub-montane plots (Fig. 8c), corresponding to an increase in the proportion of $\mathrm{NPP}_{\text {leaf }}$ diverted to alkane production from $0.02 \%$ to $0.12 \%$ across the profile.

We found divergent estimates for the upper plot (ACJ-01), depending on statistical method chosen. The median provided the lower bound estimate and indicated a low productivity at the highest site $(513 \mathrm{~g} / \mathrm{ha} / \mathrm{yr})$, similar to that of the low productivity sites in the sub-montane forests. While some species, including the co-dominant species (Clethra cuneata and Weinmannia fagaroides), had high alkane concentration, they varied between individuals, so the weighted standard error likely underestimated uncertainty. We therefore find that our estimates at the highest site are not robust to statistical choices and we present the range of estimates for this plot, as a measure of uncertainty here.

\section{Discussion}

\subsection{Distribution of n-alkanes}

From our tropical tree dataset, we can analyze the patterns of leaf wax $n$-alkane distributions. In any one species, individual odd $n$-alkanes in the range $\mathrm{C}_{21}$ to $\mathrm{C}_{35}$ may be dominant and distributions vary between species and with species turnover across the transect. The implications are that not all chain lengths can be followed across an environmental gradient and no $n$-alkane is a unique 'marker' for a species. The mean molecular abundance distribution (Fig.

2) shows two $n$-alkanes dominate overall: $\mathrm{C}_{29}$ and $\mathrm{C}_{31}$. They may serve as biomarkers in 
widespread sedimentary applications, whereas other homologs have more limited sources. $\mathrm{C}_{29}$ and $\mathrm{C}_{31}$ dominance in other studies of $\mathrm{C}_{3}$ trees in the rainforests of Cameroon, Africa has been observed (Garcin et al., 2014), but this is the first such demonstration from so many species at the warm and wet extremes of global calibration efforts (Sachse et al., 2012) and from the rainforests of Perú. In sedimentary archives, $\mathrm{C}_{29}$ and $\mathrm{C}_{31}$ are common analytical targets because of their abundance. For example, $\mathrm{C}_{31}$ was the dominant homolog in marine sediments of Site 1077 receiving input from the Congo rainforest, Africa and the target for $\mathrm{C}_{3}$ vs. $\mathrm{C}_{4}$ vegetation reconstruction (Schefuss et al., 2003), and $\mathrm{C}_{29}$ was the dominant homolog in marine sediments from GeoB 6519-1 used for paleohydrological reconstruction from hydrogen isotopic composition (Schefuss et al., 2005). Our study of Peruvian trees would suggest that both these chain lengths are characteristic of tropical trees.

While $\mathrm{C}_{29} / \mathrm{C}_{31}$ has been suggested as an Andean forest marker (Jansen et al., 2008), separating high elevation grassland $(<1)$ from Andean forests $(>1)$ in that study for Ecuador. Here, we find high values (> 10) in a few tree species - Weinmannia bangii, Hedyosmum goudotianum and $H$. cuatrecazanum - whereas most tree species, have values $<10$. Overall site median values range from 0.9 to 3.3 in this forested transect, with values $<1$ in so many species (especially lowland tree species) that we suggest chain length distributions may not be a secure marker for forestgrassland transition without additional evidence from pollen (Jansen et al., 2013).

In sedimentary applications, CPI is often considered when evaluating plant source, and here we find the expected odd chain length preference. But, we note that CPI values $<4$ are found in 80 individual plants, or $15 \%$ of the tropical trees sampled, so the use of CPI to diagnose plant sources vs. diagenesis or petrogenic sources should acknowledge the diversity of molecular distributions seen in living (tropical) plants, consistent with the findings of Bush and McInerney 
(2013). In particular, the low CPI in 15\% of the trees here, would suggest that caution or further quantification of these effects might be appropriate in mixing model deconvolution efforts separating plant and petrogenic sources (Pearson and Eglinton, 2000).

\section{2. $A C L$}

Alkane ACL tends to increase towards lower elevation (Fig. 4) and this has been hypothesized to be due to higher temperature. However, the overall $15.4{ }^{\circ} \mathrm{C}$ increase across $3.3 \mathrm{~km}$ results in only a one carbon increase in site mean ACL. We also note substantial variability between individuals (Fig. 4). While the central tendency of ACL is to decrease with elevation, the low temperature sensitivity and high taxonomic variability leads us to discount ACL as a proxy for temperature, at least in these TR and TMCF ecosystems. The response to temperature is not sensitive enough to be compelling for application to paleoenvironmental reconstruction, given the $2 \mathrm{x}$ to $5 \mathrm{x}$ greater variance of ACL within a site. In contrast, a temperate, latitudinal transect of soils concluded that there was a temperature dependence of ACL (Bush and McInerney, 2015). That study found a 2 carbon increase in ACL where mean annual temperature spanned $2-22{ }^{\circ} \mathrm{C}$, and summer temperature spanned $18-30{ }^{\circ} \mathrm{C}$ (Bush and McInerney, 2015). Given the low sensitivity to temperature, and the plant-to-plant variability (our study; Bush and McInerney, 2013), we suggest that ACL is unlikely to be useful for paleothermometry applications.

\subsection{Higher n-alkane concentration on plant leaves with elevation}

Our results show that some tree species in the TMCF produce more $n$-alkanes than tree species in the lowland rainforest (Fig. 5). The increase likely confers certain benefits to the leaf for defense and structure. Although herbivory is a major pressure in tropical forests, it decreases with elevation (Metcalfe et al., 2014) and is therefore unlikely to explain the increase in इalk with elevation in the montane zone, but may explain the higher alkane concentration in the lowland 
sites (TAM-05 and -06) than the sub-montane zone (PAN-02 and -03; Fig. 6b). We note an increase in mean and median $n$-alkane concentration (Fig. 6b) between SPD-02 and SPD-01, bracketing the cloud base ca. $1.5 \mathrm{~km}$ (Halladay et al., 2012a). Both sites are in a very wet climatic zone, with ca. $5 \mathrm{~m} \mathrm{MAP,}$ and the need to shed precipitation and provide structural support is unlikely to differ substantially between the two sites. We hypothesize that frequent fog immersion promotes epiphyll growth, and that wax provides a barrier to ephiphylls, fungi and other pathogens (Koch et al., 2009). Alternatively, or additionally, steeper slopes lead to more marginal conditions at SPD-01 (Table 1), modifying stature and leaf physiological tendencies.

The maximum $\Sigma$ alk values of some individuals and species continue to rise at higher elevation (Fig 6a), suggesting a connection with temperature, although median values drop at the highest site (ACJ-01 at $3537 \mathrm{~m}$; Fig 6b). While wax may also be involved in shielding against UV-B radiation at these highest altitudes, where cloud cover and atmosphere are thin, we do not find robust evidence for this response. Although $n$-alkane concentration may have different selective pressures globally, in this elevation transect we find the main difference to be between the lowland rainforest and the TMCF (Fig. 6b). Thus, we conclude that cloud immersion and low temperature lead to high $n$-alkane concentration.

\subsection{Leaf wax trait diversity in the context of species diversity}

Given the high beta diversity (Condit et al., 2002), site-to-site variation in leaf wax traits is accompanied by species replacement. Hence, changes in plot-level waxiness are more likely related to species (as well as genus and family) turnover of a phylogenetically conservative trait (Eglinton et al., 1962; Eglinton and Hamilton, 1963), rather than through intra-specific plasticity. While this question cannot be resolved here (without transplanting species for example), our 
study offers insights from the few species present at more than one site. Out of only 23 species at more than 1 site, most occur within sites $<300 \mathrm{~m}$, a narrow environmental range. Of these species, 11 show decreasing ACL values and 6 an increase in leaf wax alkane concentration with elevation, and only 2 (Caryocar pallidum, Clusia elliptica) show both. Our findings are consistent with the hypothesis that long term evolutionary response dominates the selection of leaf wax traits across the environmental gradient, rather than recent selective filtering in response to environment. A particularly strong driver appears to be long term adaptation to cloud forest or extreme high elevation environment by plant families with waxy leaves. Controlled experiments in the laboratory, or translocation experiments along the elevation profile, could directly test whether leaf wax traits can adjust to rapid environmental change, or if they are fixed by their taxonomy, with slower evolutionary response.

\subsection{Community-weighted averaging of leaf wax traits}

Sampling was guided by census data such that sample distribution and the unweighted median and mean of the sample set may be representative of the forest plot population. In the diverse lowland forest plots $(<1 \mathrm{~km})$ sampling included species representing $18-49 \%$ of plot basal area, whereas at upland sites $(>1 \mathrm{~km})$ the greater dominance meant that we achieved a higher rate of representation, with $36-73 \%$ of species basal area sampled (Fig. 6, Appendix A).

We further calculate species means and account for the biomass and dominance of these species to achieve community-weighted means. The approach is designed to achieve proportional representation of species-means, but small samples of each species, and high interspecies variability, particularly for a trait with skewed distributions, means that high values can bias both species and plot means. While we report the community-weighted mean estimate, we find the unweighted median to be the more appropriate choice given the skewness in this plant trait, 
although the community weighted mean may be the approach of choice for other traits, such as isotopic composition of the leaf components, which have less skewed distributions (e.g. Feakins et al., 2016).

Given large sample sizes of individuals, unweighted central estimates may provide a robust approximation of the central value of the forest plot population (Paine et al., 2015, Asner et al., 2016b). Community weighting schemes may better account for the dominance of tree species, particularly in upper TMCF locations where species dominance increases (e.g. Weinmannia); but species-based weighting schemes are subject to uncertainty introduced by large intraspecific variation in traits. Intraspecies variability remains to be explained, but may relate to differences in leaf age. Given the higher intraspecies variability and small samples (typically 3-5 individuals of each species), under-sampling of within species variability contributes unquantifiable uncertainty to the community-weighted mean. Comparison between methods provides a measure of that uncertainty. We find that community-weighting has the greatest impact on $n$-alkane concentration at the highest site in the TMCF (Fig. 7b), where some of the waxier leaves are found, and where fewer species have greater dominance. At this location the communityweighted mean is double that of the unweighted mean, and is many times greater than the median (Fig. 7b). With community representation, we find a strong linear increase in $n$-alkane concentration with elevation, whereas for the unweighted mean, values plateau, or even decrease for the median at the highest site, leaving our central estimates highly divergent and uncertain at this altitude $(3.7 \mathrm{~km})$.

\subsection{A concerted foliar strategy}

The increase in $n$-alkane concentration with elevation can also be considered part of the overall foliar investment strategy. Increase in LMA with elevation has been linked to the monotonic 
decline in temperature with elevation as well as limiting nutrients (Poorter et al., 2009) and particularly Ca (Asner and Martin, 2016), which may inhibit growth and canopy stature and lead plants to redirect resources into leaves. The tendency for LMA increase with elevation in this profile has now been established from both field and remote sensing approaches to be a robust feature in this tropical forest (Asner et al., 2016a, b). The benefits of adding to leaf thickness, in addition to the specific protective role of wax for leaves, could explain why $n$-alkane concentration increases more steeply (x5; Fig. 7b) across the profile than LMA (x1.6; Fig. 7a). Thus, alkane concentration appears to be a sensitive ecological recorder of this environmental gradient. We hypothesize that increased leaf wax concentration and LMA have shared roots in 'economic' investment strategies in leaf construction (Wright et al., 2004; Asner et al., 2016a), as higher investments in the Andean sites are associated with longer leaf lifespan (Girardin et al., 2014a,b; Huaraca Huasco et al., 2014; Malhi et al., 2014). We find that lowland rainforest sites cluster tightly (Fig. 7c) and that TMCF plots have higher and more variable values for both metrics, and there is substantial variation in our estimates depending on the statistical choices made (illustrated). Nevertheless, we find a strong correlation between leaf $n$-alkane concentration and LMA $\left(\mathrm{r}^{2} 0.78 ; \mathrm{p}<0.05\right.$; Fig. 7c), which offers intriguing possibilities for extending theories about drivers of LMA towards understanding controls on $n$-alkane concentration.

If generally applicable, the covariation between LMA and $n$-alkane concentration (Fig. 7c) could be used to predict variation in $n$-alkane concentration from remotely sensed data across the landscape (Asner et al., 2016a, b) and from the many tropical forest ecosystems with fieldcollected LMA data (Asner and Martin, 2016). However, these predictions for $n$-alkane concentrations would need to be tested, given the wide variation in alkane concentration between 
individuals here, in particular at the highest elevation sites (Fig. 5). Future sampling might consider large pooled leaf samples rather than leaf level measurements in order to account for leaf-to-leaf variability. We caution that the relationship between $n$-alkane concentration and LMA may not extend beyond angiosperms as plant waxiness varies across phylogeny (Diefendorf et al., 2011). The latter study found no correlation between wax concentration on a mass basis and LMA, based on few species across a wide phylogenetic diversity. In that study, the angiosperms covered a narrow range of LMA compared with that sampled here. Future work could extend studies of leaf wax traits across geographic regions and phylogeny to further understand differences in foliar investment strategies. We note that this elevation transect was fully-forested and we might expect differences in transects with arid climates where thick waxy coating is also expected (Koch et al., 2009). High elevation leaf types are often referred to as 'xeromorphic' indicating the convergent evolutionary tendency of dry or high places to result in smaller, thicker, waxier leaves.

\subsection{Leaf wax productivity}

We introduce here a new concept of $\mathrm{NPP}_{\text {alk }}$, and show that in montane sectors between 0.6 and $3.7 \mathrm{~km}$, despite a decline in $\mathrm{NPP}_{\text {leaf }}$ with elevation, alkane productivity increases with elevation from 321 to $2276 \mathrm{~g} \mathrm{C} / \mathrm{ha} / \mathrm{yr}$ (forest plot median values; Table 2, Fig. 8). In terms of ecosystem net carbon fixation, the higher $\mathrm{NPP}_{\text {alk }}$ and lower $\mathrm{NPP}_{\text {leaf }}$ values in the TMCF suggests higher leaf wax production while overall leaf production declines, resulting in an increase in the proportion of foliar investment being diverted to leaf wax. The higher proportional investment in TMCF in leaves (Table 2), necessarily diverts resources from upwards growth restricting canopy height (Table 1). However, as $\mathrm{C}$ and $\mathrm{H}$ are not limiting elements for plants, wax may represent a relatively cheap investment in foliar biomass and defense. 
Additional research on living plants would ideally expand quantification of leaf wax alkane concentration and productivity in biomes around the world in order to better assess NPP alk in different ecosystems, to test whether the altitudinal trend in $\mathrm{NPP}_{\mathrm{alk}}$ is generally present. More generally, the data lead us to consider whether leaf wax production may systematically vary across other landscapes and ecosystems, and other studies of wax concentration suggest that this may be the case (Garcin et al., 2014; Diefendorf et al., 2015), although currently this cannot be compared on a unit area basis.

\subsection{Geological significance}

Although $\mathrm{NPP}_{\text {alk }}$ is a minor fraction of carbon fixation in the living forest (Table 1), we suggest that it may be geologically important. The leaf wax alkane component of biomass is more recalcitrant than other plant biochemicals (e.g. cellulose) that dominate living plant tissue. Only a few recalcitrant compounds, and a very small fraction of living forest biomass, have the potential to enter longer term carbon storage in soils, rivers and ocean sediments (Hedges and Oades, 1997). We therefore propose that $\mathrm{NPP}_{\text {alk }}$ be more widely estimated, as one of the components with the potential to be exported to soils and sediments and sequestered for millions of years (e.g. Tipple and Pagani, 2010).

$\mathrm{NPP}_{\text {alk }}$ also has implications for contemporary and palaeoecological research involving the extraction of leaf wax biomarkers from riverine (Ponton et al., 2014) and marine sediments (Hughen et al., 2004). Higher NPP alk production in TMCF would suggest higher input to soils and, given lower respiration rate and higher C stock (Clark et al., 2016), this may be compounded, leading to higher carbon stock in soils. Similarly, following erosion of soil into rivers, we might then expect over-representation (on an area basis) of mountain ecosystems in downstream sedimentary records, all else being equal. Higher $\mathrm{NPP}_{\text {alk }}$ in the TMCF vs. the 
rainforest, together with better preservation in soil at colder temperature and higher erosive potential from steep Andean slopes, lead us to the hypothesis that tropical montane forests may be disproportionately represented in geological archives, in contrast to the more productive but less waxy lowland trees. However, there are many additional steps after leaf wax production that determine the final fate of leaf wax produced by a plant. The steps include (i) decomposition in leaf litter and soils, (ii) residence time in soils on the landscape, (iii) erosion from soils into rivers, (iv) preservation during fluvial transport and (v) preservation upon deposition in sedimentary basins. Some of these steps are sensitive to climate, e.g. greater preservation at the cooler temperature in higher elevation soils and frequency of mass wasting from Andean slopes (Clark et al., 2016); yet others will depend on the degree of association with inorganic erosion via mineral-organic association in transit that may offer 'packaging' (Kleber et al., 2007). Further discussion of these sedimentary processes is beyond the scope of this study. However, we suggest the possibility of varying plant 'source-strength' identified in this ecosystem, may need to be factored into studies of catchment sourcing to accurately quantify processes of remineralization vs. preservation for catchment carbon cycling considerations. Here, our data add to the source end of the source-to-sink journey of leaf wax compounds in a tropical forest transect.

\subsection{Future work: other wax components}

In this study, we focused on obtaining a very large sample of leaf wax $n$-alkanes and their distributions but a subset of the samples was also analyzed for $n$-alkanoic acid concentration, as well as hydrogen isotopic composition (Feakins et al., 2016). n-Alkanoic acid concentration showed a strong proportional increase with elevation, but at low elevations and overall concentrations were much lower than $n$-alkane concentration in that study (alkane/acid mean $9 \pm$ 
3 , se). Similarly, a study of North American taxa has shown that $n$-alkanes are among the most abundant compounds in evergreen angiosperm leaf waxes, representing ca. $2 / 3$ of all wax components, but the proportions vary between plant types, with $n$-alkane contributions being much less in deciduous angiosperms and negligible in gymnosperms (Diefendorf et al., 2011). However globally those phylogenetic patterns are not maintained, as a later survey of taxa from outside North America found alkanes dominant in other gymnosperms that are globally and geological significant, including Southern Hemisphere conifer Podocarpaceae (Diefendorf et al., 2015).

Regarding function of the various wax components, $n$-alkanes are the most hydrophobic of the alkyl lipids and may play a key role in water-shedding and defense against cloud forest pressures. It would be valuable to quantify and characterize taxonomic and environmental variations in other wax components, which may play different roles in defense and thus might have different spatial distribution patterns. For example, terpenoids are involved in insect defense (Giri et al., 2015) and we may hypothesize that these components may decrease with increasing elevation and reduced herbivory pressure.

The insights from leaf wax $n$-alkane traits provide a geologically-useful start - these are the components best represented in the molecular fossil record. Although we found ACL had little promise as a palaeothermometer, leaf wax isotopic composition carries important information about hydroclimate (Polissar and Freeman, 2010) and for reconstructing tropical paleoecology and paleoclimate (Schefuss et al., 2003, 2005). However, other compounds, particularly $n$ alkanoic acids have been found useful in river catchment (Ponton et al., 2014) and palaeoclimate (Fornace et al., 2014) applications. Further, sedimentary studies have shown differences in compound classes upon fluvial export (Hemingway et al., 2016). Additional modern plant 
calibration studies, surveying other wax components, have the potential to expand understanding of plant sourcing of sedimentary proxies as well as the tropical forest ecological significance of the wax composition.

\section{Conclusions}

We report a large scale study of plant wax $n$-alkane concentration and distributions in tropical lowland rainforest and TMCF in Perú. Towards higher elevation, plants divert more resources to

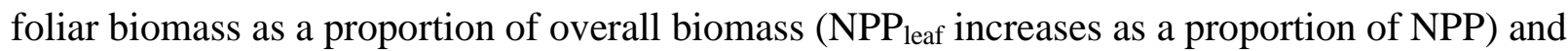
within leaf chemistry they divert more of their production to $n$-alkanes. As a result of intensive studies of these forest plots, we were able to calculate a new measure of $\mathrm{NPP}_{\text {alk. }}$ The findings are of ecological significance as plant foliar biochemical allocations may represent adaptation to environment as part of investment and defense strategies. Further testing of these concentration patterns in other elevation gradient studies would allow testing of the hypothesized links between temperature and other environmental gradients and the robustness of these patterns to ecosystem community change. The findings are of geological significance as the wax $n$-alkanes leave a legacy that remains far beyond the lifetime of the plant, in soils, rivers and ocean sediments, and they offer molecular clues to past forest production. While alkanes are a small fraction of $\mathrm{NPP}_{\text {leaf }}$ $(<0.12 \%)$ they survive post-mortem and contribute to long term $\mathrm{C}$ sequestration in soils and sediments. Connections to studies of leaf wax concentrations in soils and sediments would allow characterization of how these production changes translate into sedimentary sequestration.

\section{Acknowledgements}

The authors are part of the Andes Biodiversity and Ecosystems Research Group ABERG (andesresearch.org), the Global Ecosystems Monitoring (GEM) network (gem.tropicalforests.ox.ac.uk) and the Amazon Forest Inventory Network RAINFOR (www.rainfor.org) research consortia. Field 
sampling: The field campaign was funded by grants to Y.M. from the UK Natural Environment Research Council (Grants NE/D01025X/1, NE/D014174/1). The research leading to these results has received funding from the European Research Council under the European Union's Seventh Framework Programme (FP/2007-2013)/ERC Grant Agreement no. 321131 and 291585 (GEM-TRAITS and TFORCES) as well as the Jackson Foundation to Y.M. and a John D. and Catherine T. MacArthur Foundation grant to G.A. G.A. and the spectranomics team were supported by an endowment from the Carnegie Institution for Science, and by the US National Science Foundation (DEB-1146206), supporting the taxonomic contributions to the project. Carnegie Airborne Observatory data collection, processing and analyses were funded solely by the John D. and Catherine T. MacArthur Foundation. The Carnegie Airborne Observatory is supported by the Avatar Alliance Foundation, John D. and Catherine T. MacArthur Foundation, Andrew Mellon Foundation, David and Lucile Packard Foundation, Mary Anne Nyburg Baker and G. Leonard Baker Jr., and William R. Hearst III (all USA). Laboratory work at USC: This material is based upon work supported by the US National Science Foundation under Grant No. EAR-1227192 to S.F. Acknowledgment is made to the donors of the American Chemical Society Petroleum Research Fund for partial support of the research (53747-ND2) to S.F. In Perú, we thank the Servicio Nacional de Áreas Naturales Protegidas por el Estado (SERNANP) and personnel of Manu and Tambopata National Parks for logistical assistance and permission to work in the protected areas. We also thank the Explorers' Inn and the Pontifical Catholic University of Perú (PUCP), as well as Amazon Conservation Association for use of the Tambopata and Wayqecha Research Stations, respectively. Many researchers were involved in the field; in particular we would like to thank E. Cosio, W. Huaraca-Huasca and J. Huaman for advising on field logistics; tree climbers, C. Costas, D. Chacón, H. Ninatay; field project supervision, T. Boza, M. Raurau; species identification and basal area, W. Farfan, F. Sinca; leaf areas, R.M. Castro, G. Rayme, A. Robles, Y. Choque and Y. Valdez. We thank USC undergraduate J. Sunwoo for laboratory assistance. This manuscript was improved with the comments of A.F. Diefendorf and an anonymous reviewer. 


\section{Appendix a. Supplementary data}

Supplementary data associated with this article can be found, in the online version, at

http://dx.doi.org/10..... The data include interactive Google Earth maps of the sampling locations.

Associate Editor - P.A. Meyers

\section{References}

Asner, G.P., Anderson, C.B., Martin, R.E., Knapp, D.E., Tupayachi, R., Sinca, F., Malhi, Y., 2014a. Landscape-scale changes in forest structure and functional traits along an Andesto-Amazon elevation gradient. Biogeosciences 11, 843-856.

Asner, G.P., Llactayo, W., Tupayachi, R., Luna, E.R., 2013. Elevated rates of gold mining in the Amazon revealed through high-resolution monitoring. Proceedings of the National Academy of Sciences of the USA, 110, 18454-18459.

Asner, G.P., Martin, R.E., Carranza-Jimenez, L., Sinca, F., Tupayachi, R., Anderson, C.B. and Martinez, P., 2014b. Functional and biological diversity of foliar spectra in tree canopies throughout the Andes to Amazon region. New Phytologist 204, 127-139.

Asner, G.P., Knapp, D.E., Anderson, C.B., Martin, R.E., Vaughn, N., 2016a. Large-scale climatic and geophysical controls on the leaf economics spectrum. Proceedings of the National Academy of Sciences, doi:10.1073/pnas.1604863113.

Asner, G.P., Martin, R.E., Anderson, C.B., Kryston, K., Vaughn, N., Knapp, D.E., Bentley, L.P., Shenkin, A., Salinas, N., Sinca, F., Tupayachi, R., Quispe Huaypar, K., Montoya Pillco, M., Ccori Álvarez, F.D., Díaz, S., Enquist, B., Malhi, Y., 2016b. Scale dependence of canopy trait distributions along a tropical forest elevation gradient. New Phytologist, doi:10.1111/nph. 14068 .

Asner, G.P. and Martin, R.E., 2016. Convergent elevation trends in canopy chemical traits of tropical forests. Global Change Biology, 22, 2216-2227.

Baker, P.A., Fritz, S.C., Silva, C.G., Rigsby, C.A., Absy, M.L., Almeida, R.P., Caputo, M., Chiessi, C.M., Cruz, F.W., Dick, C.W., Feakins, S.J., Figueiredo, J., Freeman, K.H., Hoorn, C., Jaramillo, C., Kern, A.K., Latrubesse, E.M., Ledru, M.P., Marzoli, A., Myrbo, A., Noren, A., Piller, W.E., Ramos, M.I.F., Ribas, C.C., Trnadade, R., West, A.J., Wahnfried, I., Willard, D.A., 2015. Trans-Amazon Drilling Project (TADP): origins and evolution of the forests, climate, and hydrology of the South American tropics. Scientific Drilling 20, 41-49.

Bingham, E.M., McClymont, E.L., Valiranta, M., Mauquoy, D., Roberts, Z., Chambers, F.M., Pancost, R.D., Evershed, R.P., 2010. Conservative composition of $n$-alkane biomarkers in Sphagnum species: implications for palaeoclimate reconstruction in ombrotrophic peat bogs. Organic Geochemistry 41, 214-220.

Bush, R.T., McInerney, F.A., 2013. Leaf wax n-alkane distributions in and across modern plants: Implications for paleoecology and chemotaxonomy. Geochimica et Cosmochimica Acta 117, 161-179.

Carr, A.S., Boom, A., Chase, B.M., 2010. The potential of plant biomarker evidence derived from rock hyrax middens as an indicator of palaeoenvironmental change. Paleogeography Paleoclimatology Paleoecology 285, 321-330. 
Castaneda, I.S., Mulitza, S., Schefuss, E., Lopes dos Santos, R.A., Sinninghe Damsté, J.S., Schouten, S., 2009. Wet phases in the Sahara/Sahel region and human migration patterns in North Africa. Proceedings of the National Academy of Sciences of the USA 106, 20159-20163.

Clark, K.E., West, A.J., Hilton, R.G., Asner, G.P., Quesada, C.A., Silman, M.R., Saatchi, S.S., Farfan-Rios, W., Martin, R.E., Horwath, A.B., Halladay, K., New, M., Malhi, Y., 2016. Storm-triggered landslides in the Peruvian Andes and implications for topography, carbon cycles, and biodiversity. Earth Surface Dynamics 3, 631-688.

Condit, R., Pitman, N., Leigh, E.G., Chave, J., Terborgh, J., Foster, R.B., Nunez, P., Aguilar, S., Valencia, R., Villa, G., Muller-Landau, H.C., Losos, E., Hubbell, S.P., 2002. Betadiversity in tropical forest trees. Science 295, 666-669.

Diefendorf, A.F., Freeman, K.H., Wing, S.L., Graham, H.V., 2011. Production of $n$-alkyl lipids in living plants and implications for the geologic past. Geochimica et Cosmochimica Acta $75,7472-7485$.

Diefendorf, A.F., Leslie, A.B., Wing, S.L., 2015. Leaf wax composition and carbon isotopes vary among major conifer groups. Geochimica et Cosmochimica Acta 170, 145-156.

Eglinton, G., Gonzalez, A.G., Hamilton, R.J., Raphael, R.A., 1962. Hydrocarbon constituents of the wax coatings of plant leaves: A taxonomic survey. Phytochemistry 1, 89-102.

Eglinton, G., Hamilton, R.J., 1963. The Distribution of alkanes. In: Swain, T., (Ed.), Chemical Plant Taxonomy. Academic Press, pp. 187-217.

Eglinton, G., Hamilton, R.J., 1967. Leaf epicuticular waxes. Science 156, 1322-1335.

Feakins, S.J., Bentley, L.P., Salinas, N., Shenkin, A., Blonder, B., Goldsmith, G.R., Ponton, C., Arvin, L.J., Wu, M.S., Peters, T., West, A.J., Martin, R.E., Enquist, B.J., Asner, G.P., Malhi, Y. 2016. Plant leaf wax biomarkers capture gradients in hydrogen isotopes of precipitation from the Andes and Amazon. Geochimica et Cosmochimica Acta 182, 155 172.

Fornace, K.L., Hughen, K.A., Shanahan, T.M., Fritz, S.C., Baker, P.A., Sylva, S.P., 2014. A 60,000-year record of hydrologic variability in the Central Andes from the hydrogen isotopic composition of leaf waxes in Lake Titicaca sediments. Earth and Planetary Science Letters 408, 263-271.

Garcin, Y., Schefuß, E., Schwab, V.F., Garreta, V., Gleixner, G., Vincens, A., Todou, G., Séné, O., Onana, J.-M., Achoundong, G., Sachse, D., 2014. Reconstructing $\mathrm{C}_{3}$ and $\mathrm{C}_{4}$ vegetation cover using $n$-alkane carbon isotope ratios in recent lake sediments from Cameroon, Western Central Africa. Geochimica et Cosmochimica Acta 142, 482-500.

Girardin, C.A.J., Espejob, J.E.S., Doughty, C.E., Huasco, W.H., Metcalfe, D.B., Durand-Baca, L., Marthews, T.R., Aragao, L., Farfan-Rios, W., Garcia-Cabrera, K., Halladay, K., Fisher, J.B., Galiano-Cabrera, D.F., Huaraca-Quispe, L.P., Alzamora-Taype, I., EguiluzMora, L., Salinas-Revilla, N., Silman, M.R., Meir, P., Malhi, Y., 2014a. Productivity and carbon allocation in a tropical montane cloud forest in the Peruvian Andes. Plant Ecology and Diversity 7, 107-123.

Girardin, C.A.J., Farfan-Rios, W., Garcia, K., Feeley, K.J., Jorgensen, P.M., Murakami, A.A., Perez, L.C., Seidel, R., Paniagua, N., Claros, A.F.F., Maldonado, C., Silman, M., Salinas, N., Reynel, C., Neill, D.A., Serrano, M., Caballero, C.J., Cuadros, M.D.L., Macia, M.J., Killeen, T.J., Malhi, Y., 2014b. Spatial patterns of above-ground structure, biomass and composition in a network of six Andean elevation transects. Plant Ecology and Diversity 7, 161-171. 
Giri, S.J., Diefendorf, A.F., Lowell, T.V., 2015. Origin and sedimentary fate of plant-derived terpenoids in a small river catchment and implications for terpenoids as quantitative paleovegetation proxies. Organic Geochemistry 82, 22-32.

Graham, H.V., Patzkowsky, M.E., Wing, S.L., Parker, G.G., Fogel, M.L., Freeman, K.H., 2014. Isotopic characteristics of canopies in simulated leaf assemblages. Geochimica et Cosmochimica Acta 144, 82-95.

Handley, L., O'Halloran, A., Pearson, P.N., Hawkins, E., Nicholas, C.J., Schouten, S., McMillan, I.K., Pancost, R.D., 2012. Changes in the hydrological cycle in tropical East Africa during the Paleocene-Eocene Thermal Maximum. Paleogeography Paleoclimatology Paleoecology 329, 10-21.

Hedges, J.I. and Oades, J.M., 1997. Comparative organic geochemistries of soils and marine sediments. Organic Geochemistry 27, 319-361.

Hemingway, J.D., Schefuß, E., Dinga, B.J., Pryer, H., Galy, V., 2016. Multiple plant-wax compounds record differential sources and ecosystem structure in large river catchments. Geochimica et Cosmochimica Acta 184, 20-40.

Hoffmann, B., Kahmen, A., Cernusak, L.A., Arndt, S.K., Sachse, D., 2013. Abundance and distribution of leaf wax $n$-alkanes in leaves of Acacia and Eucalyptus trees along a strong humidity gradient in northern Australia. Organic Geochemistry 62, 62-67.

Hoorn, C., Wesselingh, F.P., ter Steege, H., Bermudez, M.A., Mora, A., Sevink, J., Sanmartin, I., Sanchez-Meseguer, A., Anderson, C.L., Figueiredo, J.P., Jaramillo, C., Riff, D., Negri, F.R., Hooghiemstra, H., Lundberg, J., Stadler, T., Sarkinen, T., Antonelli, A., 2010 Amazonia Through Time: Andean Uplift, Climate Change, Landscape Evolution, and Biodiversity. Science 330, 927-931.

Huacara Huasco, W., Girardin, C.A.J., Doughty, C.E., Metcalfe, D.B., Baca, L.D., Silva-Espejo, J.E., Cabrera, D.G., Aragao, L., Davila, A.R., Marthews, T.R., Huaraca-Quispe, L.P., Alzamora-Taype, I., Mora, L.E., Farfan-Rios, W., Cabrera, K.G., Halladay, K., SalinasRevilla, N., Silman, M.R., Meir, P., Malhi, Y., 2014. Seasonal production, allocation and cycling of carbon in two mid-elevation tropical montane forest plots in the Peruvian Andes. Plant Ecology and Diversity 7, 125-142.

Hughen, K., Eglinton, T., Xu, L., Makou, M., 2004. Abrupt tropical vegetation response to rapid climate changes. Science 304, 1955-1959.

Jansen, B., de Boer, E.J., Cleef, A.M., Hooghiemstra, H., Moscol-Olivera, M., Tonneijck, F.H., Verstraten, J.M., 2013. Reconstruction of late Holocene forest dynamics in northern Ecuador from biomarkers and pollen in soil cores. Paleogeography Paleoclimatology Paleoecology 386, 607-619.

Jansen, B., Haussmann, N.S., Tonneijck, F.H., Verstraten, J.M., de Voogt, P., 2008. Characteristic straight-chain lipid ratios as a quick method to assess past forest-paramo transitions in the Ecuadorian Andes. Paleogeography Paleoclimatology Paleoecology $262,129-139$.

Jansen, B., Nierop, K.G.J., 2009. Methyl ketones in high altitude Ecuadorian Andosols confirm excellent conservation of plant-specific $n$-alkane patterns. Organic Geochemistry 40, $61-$ 69.

Jansen, B., Nierop, K.G.J., Hageman, J.A., Cleef, A.M., Verstraten, J.M., 2006. The straightchain lipid biomarker composition of plant species responsible for the dominant biomass production along two altitudinal transects in the Ecuadorian Andes. Organic Geochemistry 37, 1514-1536. 
Jansen, B., van Loon, E.E., Hooghiemstra, H., Verstraten, J.M., 2010. Improved reconstruction of palaeo-environments through unravelling of preserved vegetation biomarker patterns. Paleogeography Paleoclimatology Paleoecology 285, 119-130.

Jetter, R. and Schaffer, S., 2001. Chemical composition of the Prunus laurocerasus leaf surface. Dynamic changes of the epicuticular wax film during leaf development. Plant Physiology 126, 1725-1737.

Kahmen, A., Schefuss, E., Sachse, D. 2013a. Leaf water deuterium enrichment shapes leaf wax n-alkane delta D values of angiosperm plants I: Experimental evidence and mechanistic insights. Geochimica et Cosmochimica Acta 111, 39-49.

Kawamura, K., Ishimura, Y., Yamazaki, K., 2003. Four years' observations of terrestrial lipid class compounds in marine aerosols from the western North Pacific. Global Biogeochemical Cycles 17 1003, 1-19.

Kleber, M., Sollins, P., Sutton, R., 2007. A conceptual model of organo-mineral interactions in soils: self-assembly of organic molecular fragments into zonal structures on mineral surfaces. Biogeochemistry 85, 9-24.

Kar, N., Garzione, C.N., Jaramillo, C., Shanahan, T., Carlotto, V., Pullen, A., Moreno, F., Anderson, V., Moreno, E., Eiler, J., 2016. Rapid regional surface uplift of the northern Altiplano plateau revealed by multiproxy paleoclimate reconstruction. Earth and Planetary Science Letters 447, 33-47.

Koch, K., Bhushan, B., Barthlott, W., 2009. Multifunctional surface structures of plants: An inspiration for biomimetics. Progress in Materials Science 54, 137-178.

Krishnan, S., Pagani, M., Agnini, C., 2015. Leaf waxes as recorders of paleoclimatic changes during the Paleocene-Eocene Thermal Maximum: Regional expressions from the Belluno Basin. Organic Geochemistry 80, 8-17.

Malhi, Y., Amezquita, F.F., Doughty, C.E., Silva-Espejo, J.E., Girardin, C.A.J., Metcalfe, D.B., Aragao, L., Huaraca-Quispe, L.P., Alzamora-Taype, I., Eguiluz-Mora, L., Marthews, T.R., Halladay, K., Quesada, C.A., Robertson, A.L., Fisher, J.B., Zaragoza-Castells, J., Rojas-Villagra, C.M., Pelaez-Tapia, Y., Salinas, N., Meir, P., Phillips, O.L., 2014. The productivity, metabolism and carbon cycle of two lowland tropical forest plots in southwestern Amazonia, Peru. Plant Ecology and Diversity 7, 85-105.

Malhi, Y., Silman, M., Salinas, N., Bush, M., Meir, P., Saatchi, S., 2010. Introduction: Elevation gradients in the tropics: laboratories for ecosystem ecology and global change research. Global Change Biology 16, 3171-3175.

Metcalfe, D.B., Asner, G.P., Martin, R.E., Silva Espejo, J.E., Huasco, W.H., Farfán Amézquita, F.F., Carranza-Jimenez, L., Galiano Cabrera, D.F., Baca, L.D., Sinca, F., Huaraca Quispe, L.P., Taype, I.A., Mora, L.E., Dávila, A.R., Solórzano, M.M., Puma Vilca, B.L., Laupa Román, J.M., Guerra Bustios, P.C., Revilla, N.S., Tupayachi, R., Girardin, C.A.J., Doughty, C.E., Malhi, Y., 2014. Herbivory makes major contributions to ecosystem carbon and nutrient cycling in tropical forests. Ecology Letters 17, 324-332.

Noble, D.C., McKee, E.H., Megard, F., 1979. Early Tertiary "Incaic" tectonism, uplift, and volcanic activity, Andes of central Peru. Geoligical Society of America Bulletin 90, 903907.

Pagani, M., Pedentchouk, N., Huber, M., Sluijs, A., Schouten, S., Brinkhuis, H., Sinninghe Damsté, J.S., Dickens, G.R., 2006. Arctic hydrology during global warming at the Palaeocene/Eocene thermal maximum. Nature 442, 671-675. 
Paine, C.E.T., Baraloto, C., Díaz, S., 2015. Optimal strategies for sampling functional traits in species-rich forests. Functional Ecology 29, 1325-1331.

Pearson, A. and Eglinton, T., 2000. The origin of $n$-alkanes in Santa Monica Basin surface sediment: a model based on compound-specific $\Delta 14 \mathrm{C}$ and $\delta^{13} \mathrm{C}$ data. Organic Geochemistry 31, 1103-1116.

Polissar, P.J. and Freeman, K.H., 2010. Effects of aridity and vegetation on plant-wax [delta]D in modern lake sediments. Geochimica et Cosmochimica Acta 74, 5785-5797.

Ponton, C., West, A.J., Feakins, S.J., Galy, V., 2014. Leaf wax biomarkers in transit record river catchment composition. Geophysical Research Letters 41, 6420-6427.

Reuter, H.I., Nelson, A., Jarvis, A., 2007. An evaluation of void filling interpolation methods for SRTM data, International Journal of Geographic Information Science. 21, 9831008.

Schefuss, E., Schouten, S., Jansen, J.H.F., Sinninghe Damsté, J.S., 2003. African vegetation controlled by tropical sea surface temperatures in the mid-Pleistocene period. Nature 422 , 418-421.

Schefuss, E., Schouten, S., Schneider, R., 2005. Climatic controls on central African hydrology during the past 20,000 years. Nature 473, 1003-1006.

Silman, M. 2011. Plant species diversity in Amazonian forests, In: Bush, M., Flenley, J., Gosling, W. (Eds.), Tropical Rainforest Responses to Climatic Change. Springer, location pp. 285-314.

Silman, M.R., 2014. Functional megadiversity. Proceedings of the National Academy of Sciences of the USA 111, 5763-5764.

Tipple, B.J., Berke, M.A., Doman, C.E., Khachaturyan, S., Ehleringer, J.R., 2013. Leaf-wax $n$ alkanes record the plant-water environment at leaf flush. Proceedings of the National Academy of Sciences of the USA 110, 2659-2664.

Tipple, B.J., Pagani, M., 2013. Environmental control on eastern broadleaf forest species' leaf wax distributions and D/H ratios. Geochimica et Cosmochimica Acta 111, 64-77.

Vogts, A., Moossen, H., Rommerskirchen, F., Rullkötter, J., 2009. Distribution patterns and stable carbon isotopic composition of alkanes and alkan-1-ols from plant waxes of African rain forest and savanna $C_{3}$ species. Organic Geochemistry 40, 1037-1054. 


\section{Figure Legends}

Fig. 1. Location of $9 \mathrm{CHAMBASA}$ forest plots on an elevation transect across the eastern slope of the Andes in southern Perú. Site locations (open circles, site name annotated), vegetation zones, cloud base and river proximity indicated. Elevation profile: gray line (elevation acquired from the Shuttle Radar Topographic Mission (SRTM) 90m Digital Elevation Database 4.1 (Reuter et al., 2007), black line (smoothed elevation), gray envelope (topography; $\pm 2 \sigma$ elevation from $1 \mathrm{~km}$ wide swath perpendicular to transect, re-centered to smoothed elevation). $\mathrm{R}$ code available from https://gist.github.com/ashenkin/7fceb77e78efc33961a8. For interactive map of study locations see Appendix A.

Fig. 2. $n$-Alkane abundance distribution, showing relative abundance distribution of all individuals $(\mathrm{n}=552)$ across all 9 sites. Variability not shown; see Appendix A.

Fig. 3. Molecular abundance indices for individual data (black $+; n=552$ ); (a) $\mathrm{C}_{29} / \mathrm{C}_{31}$ and (b) CPI.

Fig. 4. ACL, showing species mean values at each site (blue circles; $n=152$ ) overlain on individual data (black dot; $\mathrm{n}=552$ ) with unweighted site mean values (black dash symbol; $\mathrm{n}=9$ ) and linear regression of site mean values (thick black line), see text.

Fig. 5. Total alkane concentration, (a) per gram dry leaf, (b) per gram dry leaf on $\mathrm{C}$ basis and (c) per unit area, showing data for individuals $(+)$. 
Fig. 6. (a) Total alkane concentration per unit area, showing individuals (black dots), species average (blue circles) and community weighted mean (green dash symbol). (b) Violin plot (zoomed in) showing the distribution of individual data (using a Gaussian kernel density function), the median (red line) and the mean (thick black line). Also shown are community representation: fraction of basal area represented by sampling (pie charts), with number of individuals and species sampled.

Fig. 7. (a) Leaf mass per area (LMA) for forest plots, (b) total alkane concentration per leaf area and (c) LMA vs. Salk. Shown are median (red triangles), mean (black squares) and standard error of the mean (error bars), and community-weighted mean (cmw; green squares) and weighted standard error (error bars). Data cluster (demarcated by dashed lines) for the tropical lowland rainforest, as distinct from the tropical montane cloud forest, which has higher values and greater variability (note y axis break). Regression is shown for the plot mean values only (black line), $\mathrm{y}=0.14 \mathrm{x}-12\left(\mathrm{r}^{2} 0.78, \mathrm{p}<0.05\right)$.

Fig. 8. (a) Total alkane concentration on a carbon basis, showing median (red triangles), mean (black squares) showing standard error of the mean (error bars) and community-weighted mean values (green squares), showing weighted standard error of the mean (error bars). (b) $\mathrm{NPP}_{\text {leaf }}$ for each forest plot, showing standard errors (error bars) and linear regression $y=-0.53 x-3.9\left(r^{2}\right.$ 0.67, p < 0.05) (Girardin et al., 2014a; Huaraca Huasco et al., 2014; Malhi et al., 2014; and this study). (c) $\mathrm{NPP}_{\text {alk }}$ for each forest plot; symbols as in (a). 
Table 1 Environmental and ecological characteristics of 1 ha forest plots along a tropical montane elevation transect.

\begin{tabular}{|c|c|c|c|c|c|c|c|c|c|}
\hline $\begin{array}{l}\text { CHAMBASA/ } \\
\text { RAINFOR site } \\
\end{array}$ & TAM-06 & TAM-05 & PAN-02 & PAN-03 & SPD-02 & SPD-01 & TRU-04 & ESP-01 & ACJ-01 \\
\hline Latitude & -12.8385 & -12.8309 & -12.6495 & -12.6383 & -13.0491 & -13.0475 & -13.1055 & -13.1751 & -13.14689 \\
\hline Longitude & -69.2960 & -69.2705 & -71.2626 & -71.2744 & -71.5365 & -71.5423 & -71.5893 & -71.5948 & -71.6323 \\
\hline Elevation $(\mathrm{m})^{\mathrm{a}}$ & 215 & 223 & 595 & 859 & 1494 & 1713 & 2719 & 2868 & 3537 \\
\hline Slope $(\mathrm{deg})^{\mathrm{a}}$ & 2.2 & 4.5 & 11.5 & 13.7 & 27.1 & 30.5 & 21.2 & 27.3 & 36.3 \\
\hline Aspect $(\operatorname{deg})^{\mathrm{a}}$ & 169 & 186 & 138 & 160.5 & 125 & 117 & 118 & 302 & 104 \\
\hline MAAT $\left({ }^{\circ} \mathrm{C}\right)^{\mathrm{b}}$ & 24.4 & 24.4 & $23.5^{\mathrm{b}}$ & $21.9^{\mathrm{b}}$ & 18.8 & 17.4 & 13.5 & 13.1 & 9 \\
\hline Precipitation $(\mathrm{mm} / \mathrm{yr})$ & 1900 & 1900 & $2366^{\mathrm{b}}$ & $2835^{\mathrm{b}}$ & 5302 & 5302 & 2318 & 1560 & 1980 \\
\hline Vegetation height ${ }^{\mathrm{a}}$ & 28.2 & 27.5 & 24.4 & 18.7 & 22.8 & 14.0 & 15.7 & 16.9 & 12.5 \\
\hline
\end{tabular}

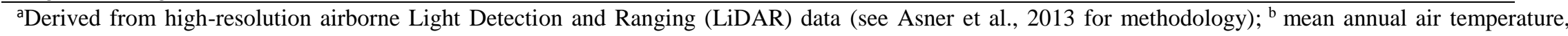
derived from observations between 6 Feb 2013 and 7 Jan 2014. 


\section{Table 2}

Leaf wax components as a component of net primary productivity (md, median; me, mean; cwm, community-weighted mean; se, standard error; wse, weighted standard error; c. wse, compound standard error of the mean, calculated as sum of squares of wse for alkane concentration and $\mathrm{NPP}_{\text {leaf }}$. Site median $\mathrm{NPP}_{\text {alk }}$ estimate is also reported as a proportion of forest NPP leaf and NPP; alkane production is $<<1 \%$ because leaf wax is a small component of forest biomass).

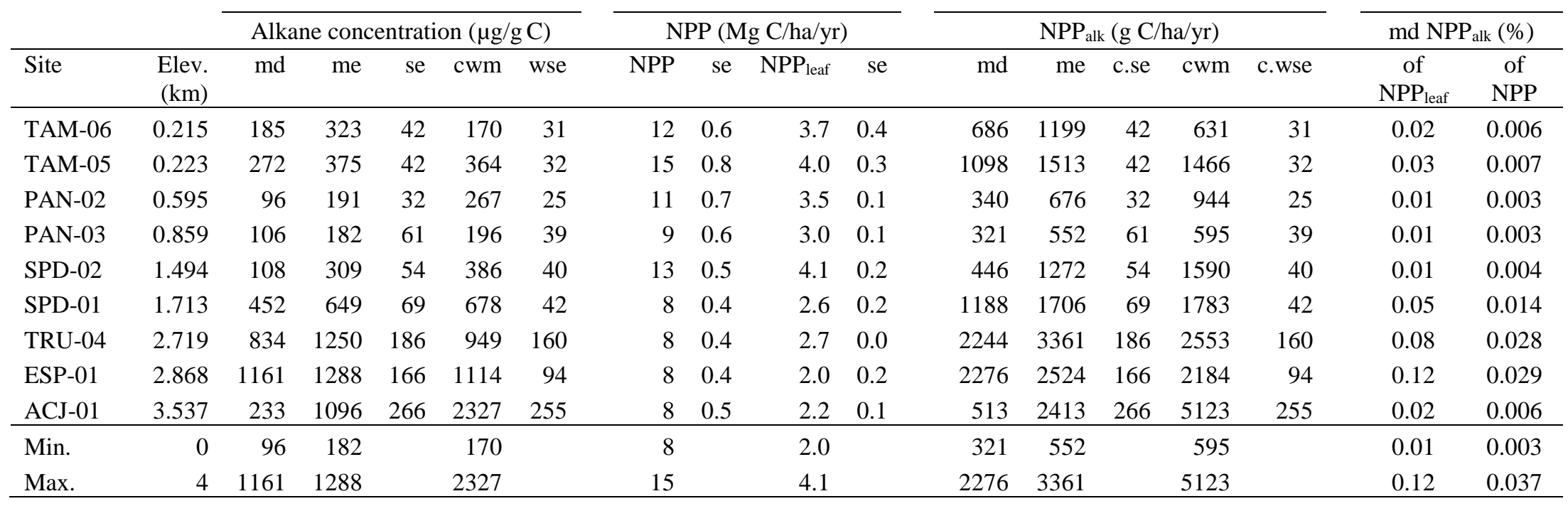




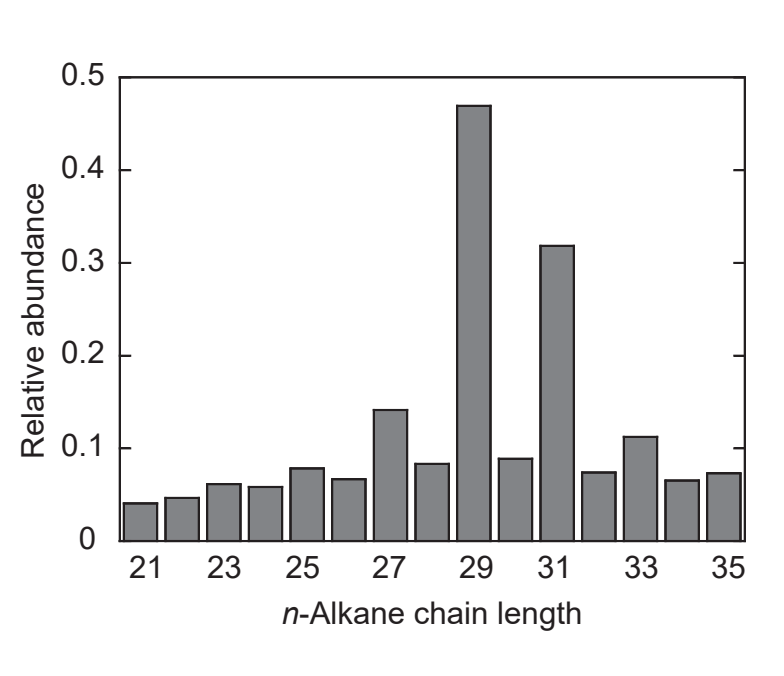

Figure 2

\section{Fure 2}

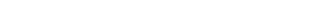

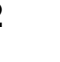

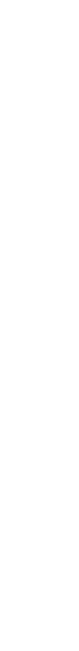

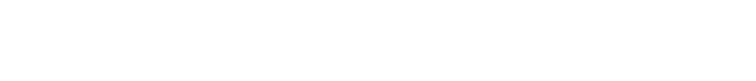



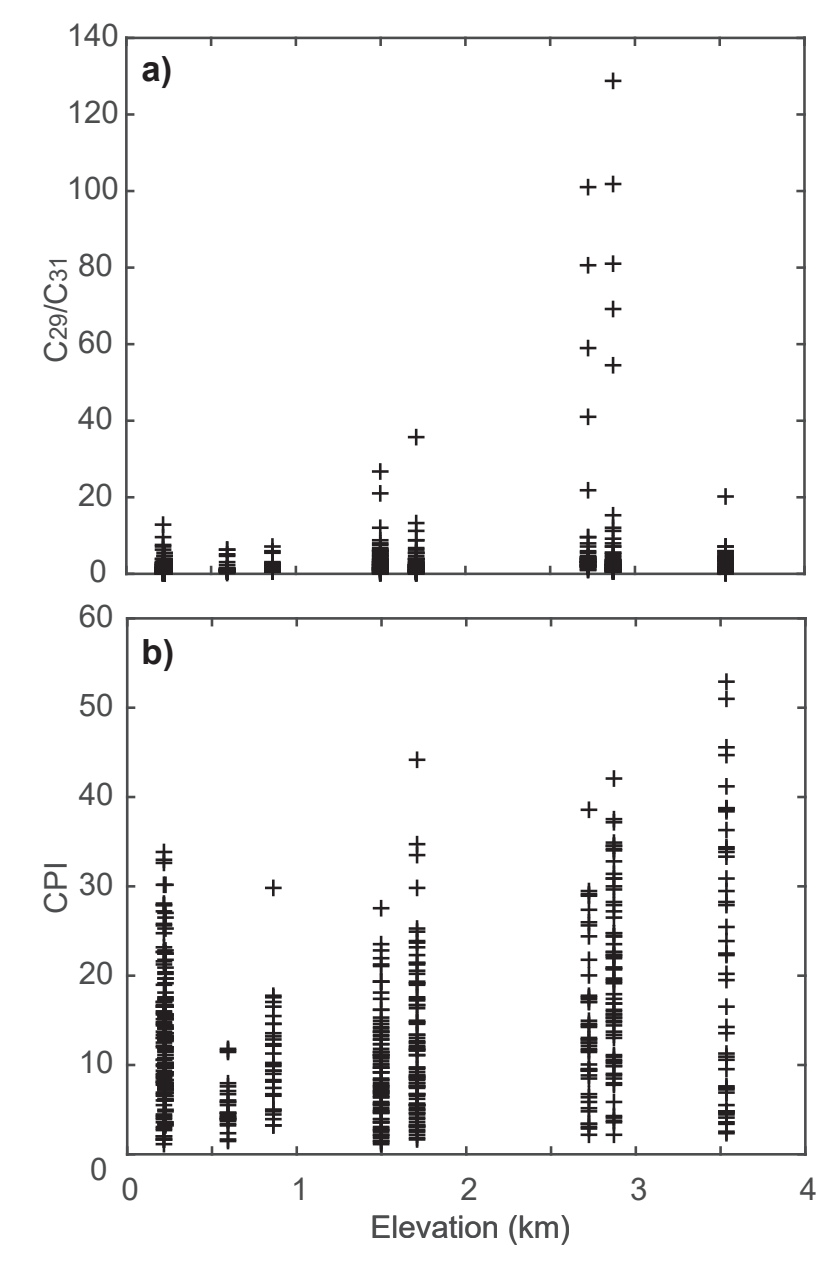

Figure 3$$
\text { (km) }
$$ 


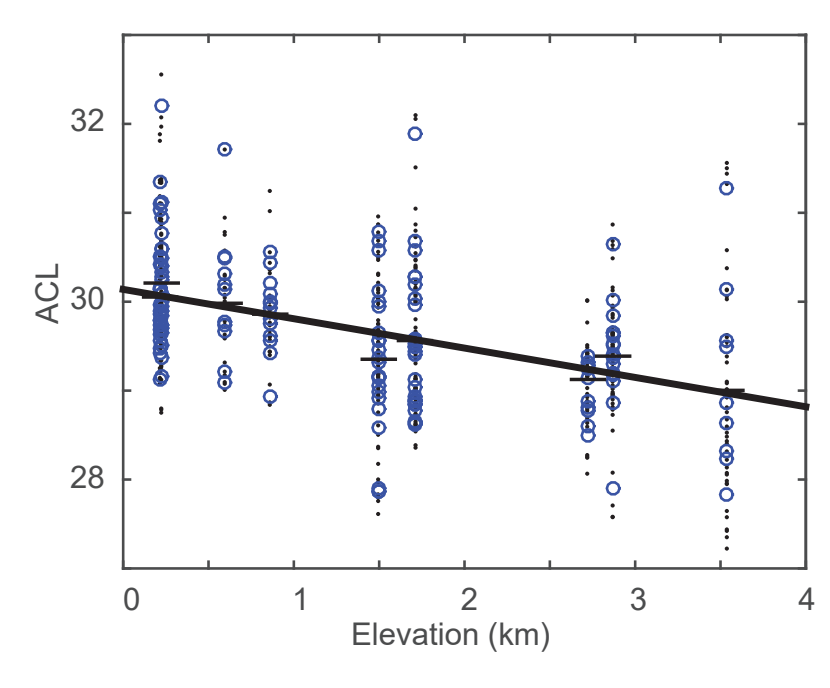

Figure 4

列

Elevation (km)

\section{Figure 4}

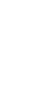


Figure 5
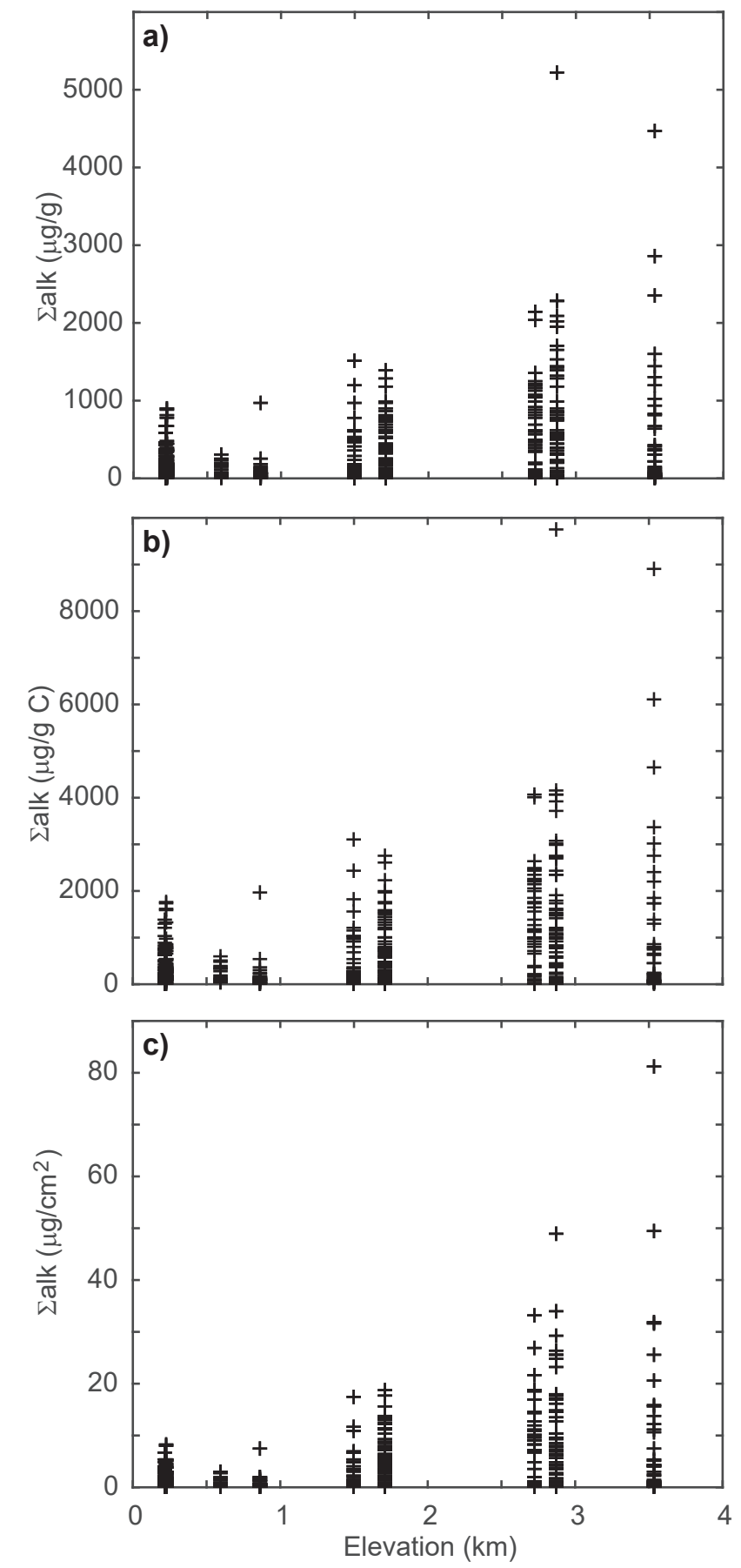


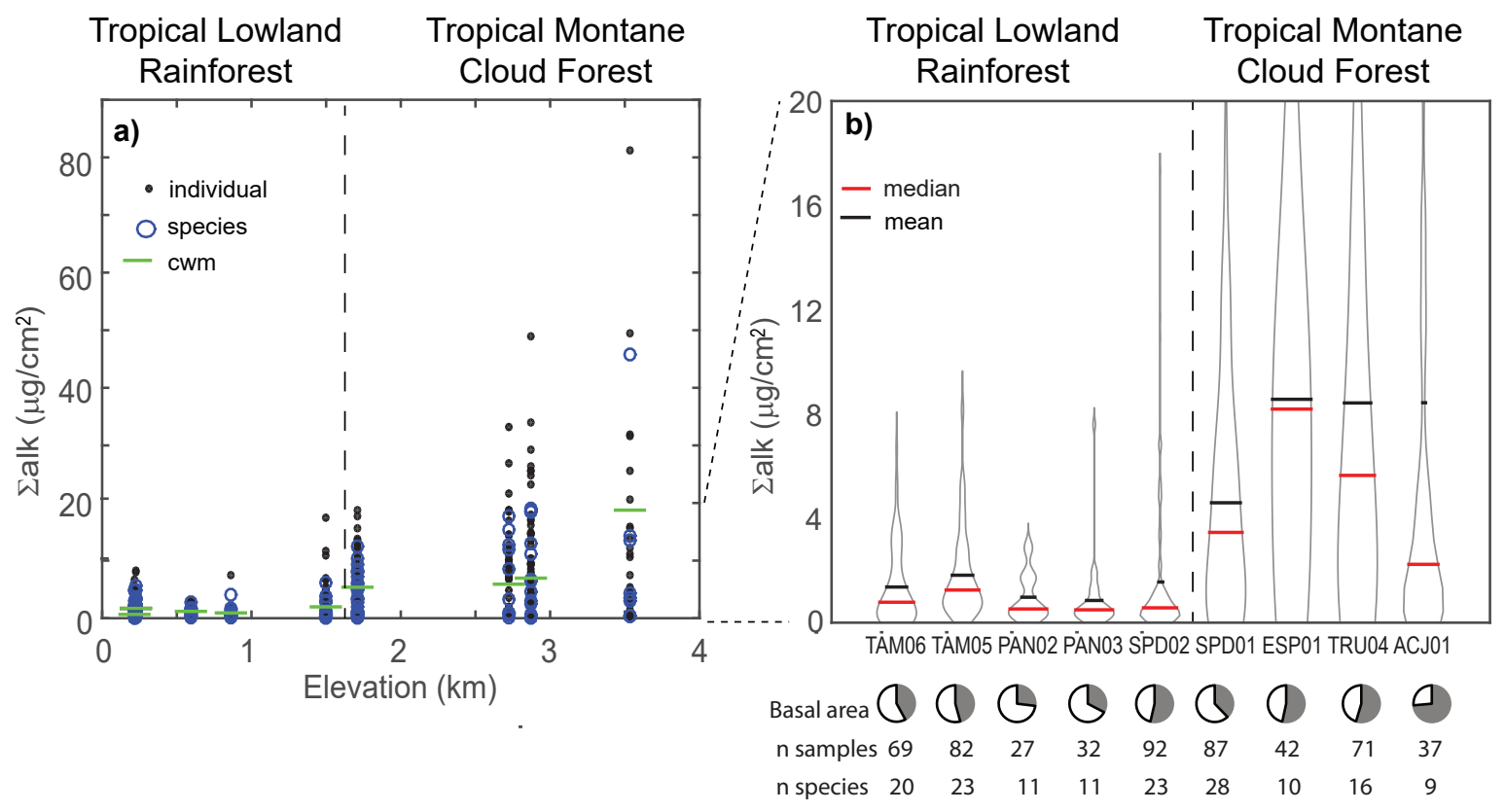


Figure 7
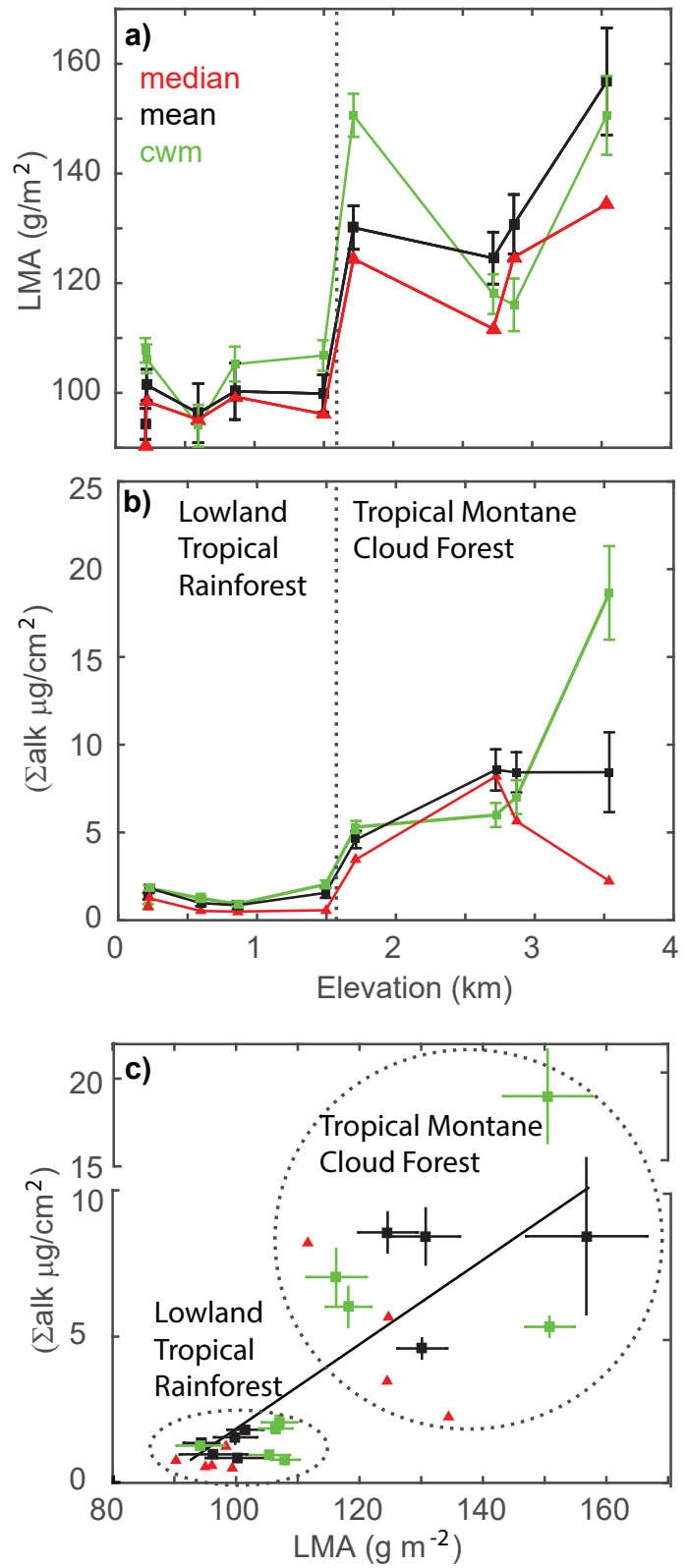
Figure 8
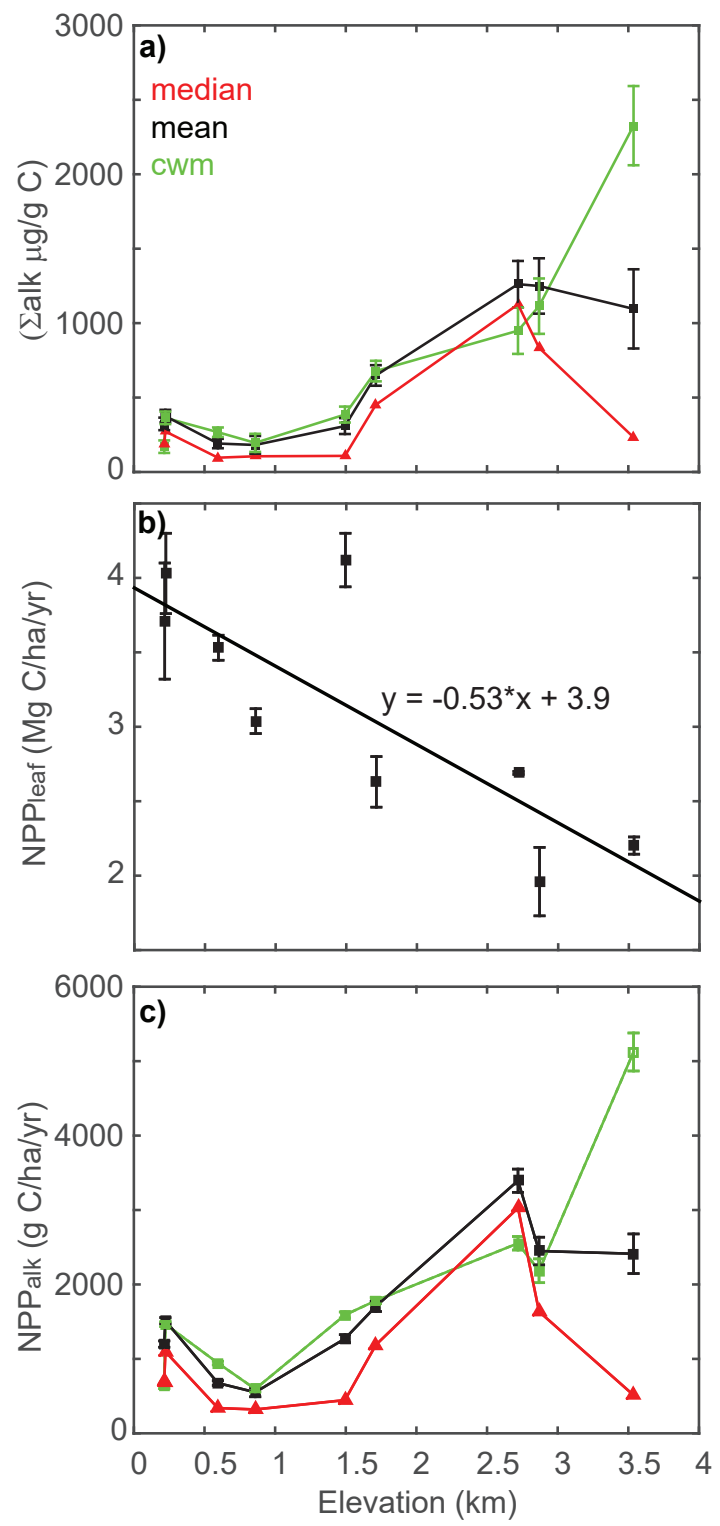